\title{
A new species of Somalina (Somalina hottingeri) with partially vacuolate lateral walls from the Middle Eocene of Oman
}

\author{
M. R. WHITE \\ Mines and Energy, South Australia, 191 Greenhill Road, Parkside, South Australia 5063, Australia.
}

\begin{abstract}
Somalina hottingeri, a new species with partially vacuolate lateral walls is described from the Middle Eocene of Oman. It is distinguished from the only previously recorded species with this wall structure ( $S$, transitorius (Hottinger)) by having equatorial chambers that are relatively low throughout the test. On the basis of this character, it is suggested that $S$. hottingeri evolved from the Opertorbitolites douvillei Group (redefined here) and that it gave rise to the true somalines. $S$. transitorius is regarded as arising from $O$. latimarginalis (ex. O. latimarginalis Group, introduced in this study) but not to have given rise to any other species.

Since forms of Somalina with only partially vacuolate walls appear to be confined to the late Early Eocene to early Middle Eocene, it is concluded that the presence of this wall structure provides a useful stratigraphic marker. J. Micropalaeontol. 16(2): 131-135, October 1997.
\end{abstract}

\section{INTRODUCTION}

The type species of Somalina ( $S$. stefaninii Silvestri, 1939; Pl. 1, fig. 1) is distinguished from that of Opertorbitolites ( $O$. douvillei Nuttall, 1925; Pl. 1, fig. 2) in having vacuolate rather than nonvacuolate lateral lamellar walls. Morphologically intermediate individuals in which the lateral walls are partially vacuolate, however, also exist (Pl. 1, figs 3-5; Pl. 2, figs 1-3).

Opertorbitolites sensu stricto first appeared in the Late Palaeocene (Alveolina cucumiformis Zone, see Opertorbitolites gracilis (Lehmann), in Lehmann, 1961) and Somalina sensu stricto is not known from rocks older than the Early Eocene (probably late Alveolina violae Zone). Since the oldest known occurrence of individuals with an intermediate morphology is also Early Eocene (A. trempina Zone; Hottinger \& Krusat, 1972), they undoubtedly represent a transitional evolutionary stage.

Hottinger (in Hottinger \& Krusat, 1972) assigned the only previously recorded species with partially vacuolate lateral walls to Opertorbitolites transitorius (Pl. 2, fig. 3). However, vacuolate lateral walls are characteristic of Somalina, to which genus these transitional forms are here assigned.

$S$. hottingeri (Pl. 1, figs 3-5, Pl. 2, figs 1-2), also with partially vacuolate lateral walls, is described below and its likely evolutionary relationships with the Opertorbitolites douvillei and $O$. latimarginalis groups, $S$. transitorius and Somalina sensu stricto are discussed.

\section{SYSTEMATIC DESCRIPTION}

The classification of Loeblich \& Tappan (1987) is followed and localities mentioned in the text are shown on Fig. 1. Range charts for each of these localities are given in White (1994), to which the reader is referred for more stratigraphical information. All specimens examined are deposited in the palaeontological collections of the Natural History Museum, London.

Suborder Miliolina Delage and Herouard, 1896

Superfamily Soritacea Ehrenberg, 1839

Family Soritidae, Ehrenberg, 1839

Genus Somalina Silvestri, 1939

Somalina hottingeri $\mathrm{n} . \mathrm{sp}$.

(Pl. 1, figs 3-5, Pl., 2, figs 1-2)

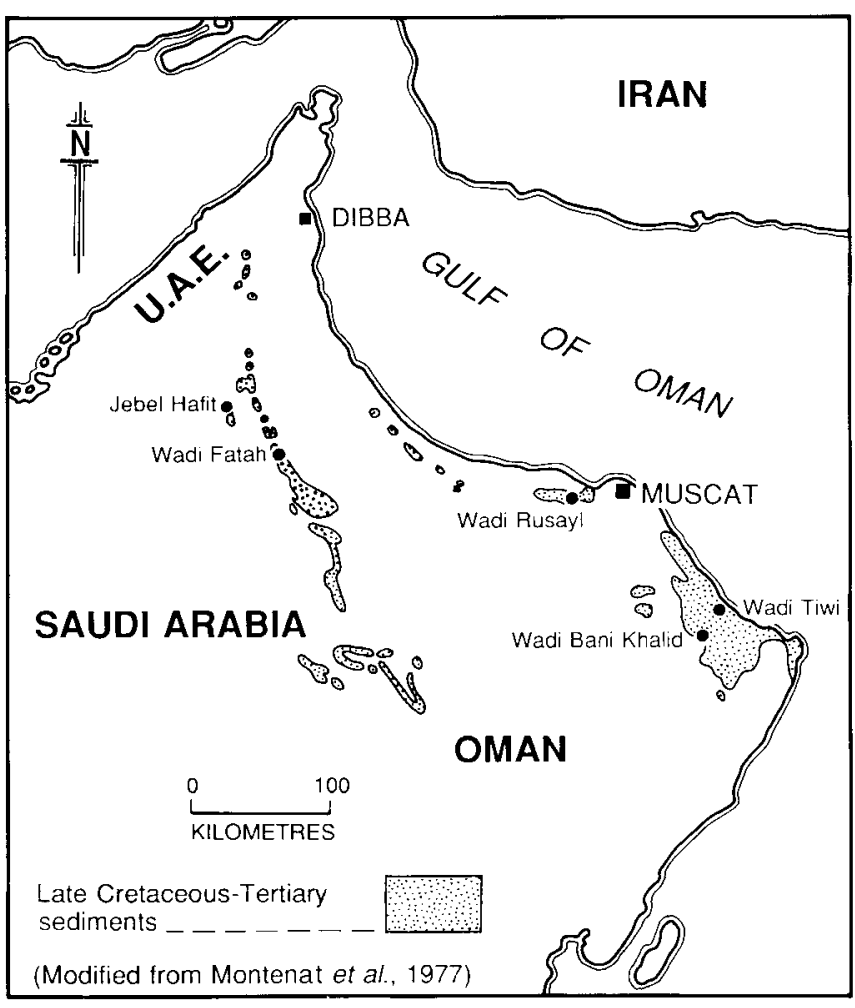

Fig. 1. Localities from which $S$. hottingeri has been recorded in Oman.

1994 Somalina n. sp.; White: figs 7, 9, 11, 12 \& 15 (range charts). Derivation of name. After Prof. L. Hottinger (Basle University), who first recorded partially vacuolate lateral lamellar walls seen in this species.

Diagnosis. Characterized by partially vacuolate lateral lamellar walls and low equatorial chambers throughout the test.

Holotype. P 52861. P1. 1, figs 3 \& 4.

Paratypes. Two oriented equatorial thin sections (P 52862 and P 52863, P1. 1, fig 5 and Pl. 2, fig. 1, respectively) and abundant specimens in random thin sections (e.g. P 52864, Pl. 2, fig. 2). 


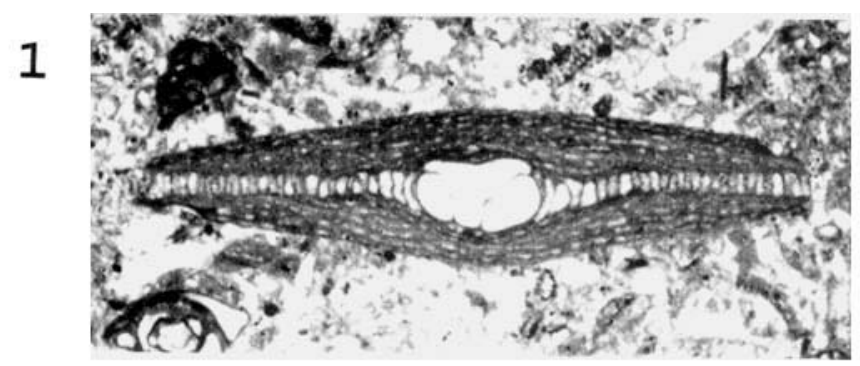

\section{2}

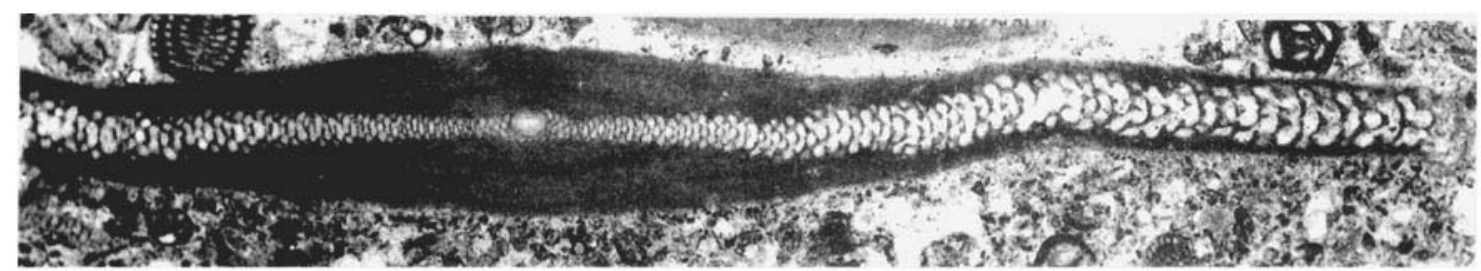

\section{3}

5

\section{4}

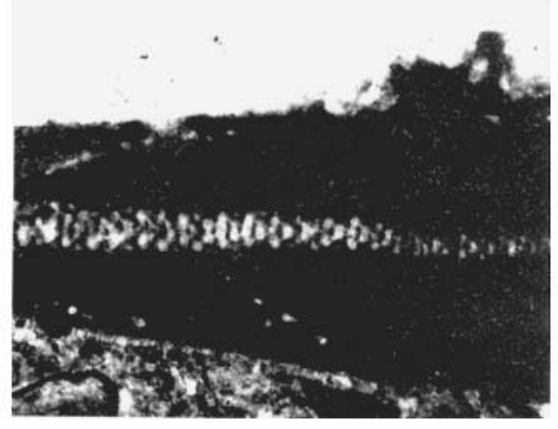

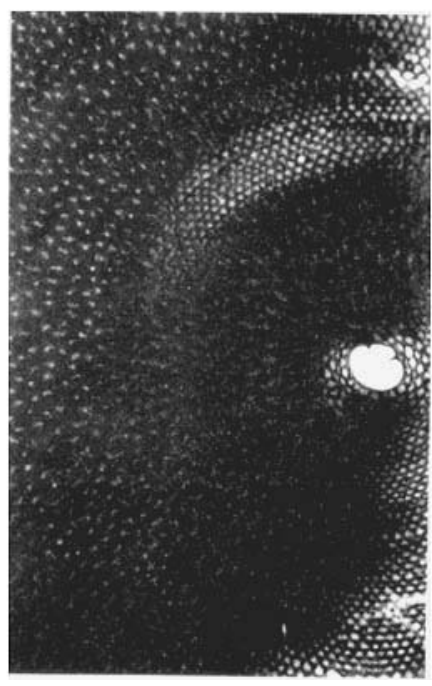

Explanation of Plate 1

Fig. 1. Somalina stephaninii Silvestri. Vertical section of a megalospheric form. Wadi Bani Khalid, WBK 10. P 52860. $\times 20$. fig. 2. Opertorbitolites douvillei Nuttall. Holotype. Vertical section of a megalospheric form. Locality 151. Parri Nala, West of Bibi Nani, Bolan Pass, Baluchistan. Figured by Nuttall (1925), Pl. 27, figs 4 \& 5. Sedgwick Collection C 2516 . $\times 15$. figs 3-5. Somalina hottingeri $\mathrm{n}$. sp: 3. Holotype. Vertical section of a megalospheric form. Wadi Fatah, F 17. P 52861, $\times 15 ;$ 4. Holotype. Enlargement of part of fig. 3 . $\times 30$. 5. Paratype. Equatorial section of a microspheric form. Wadi Rusayl, WR 33a. P 52862. $\times 15$. 


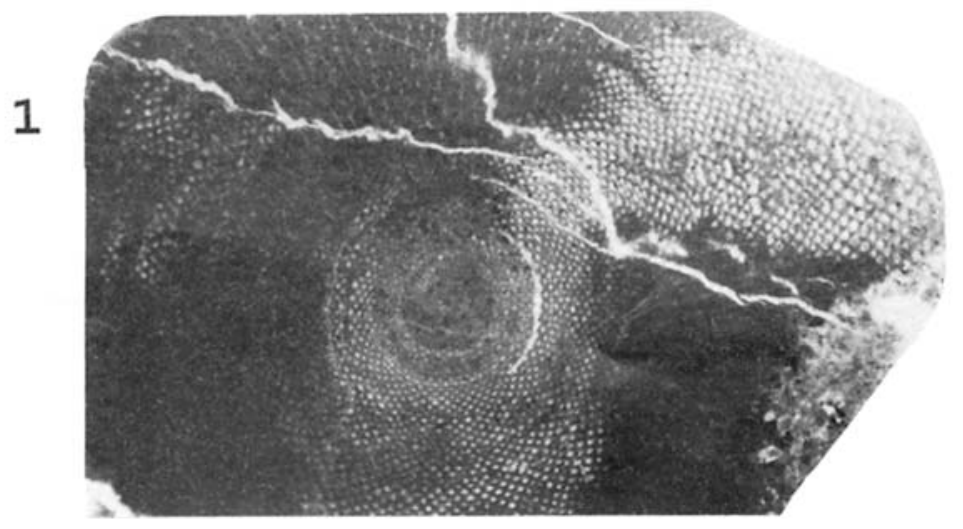

2

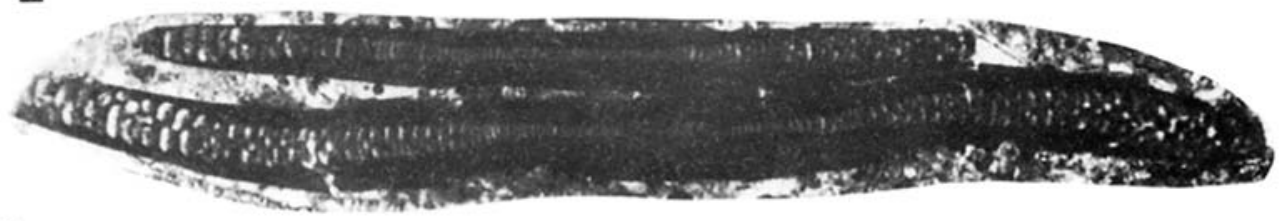

3
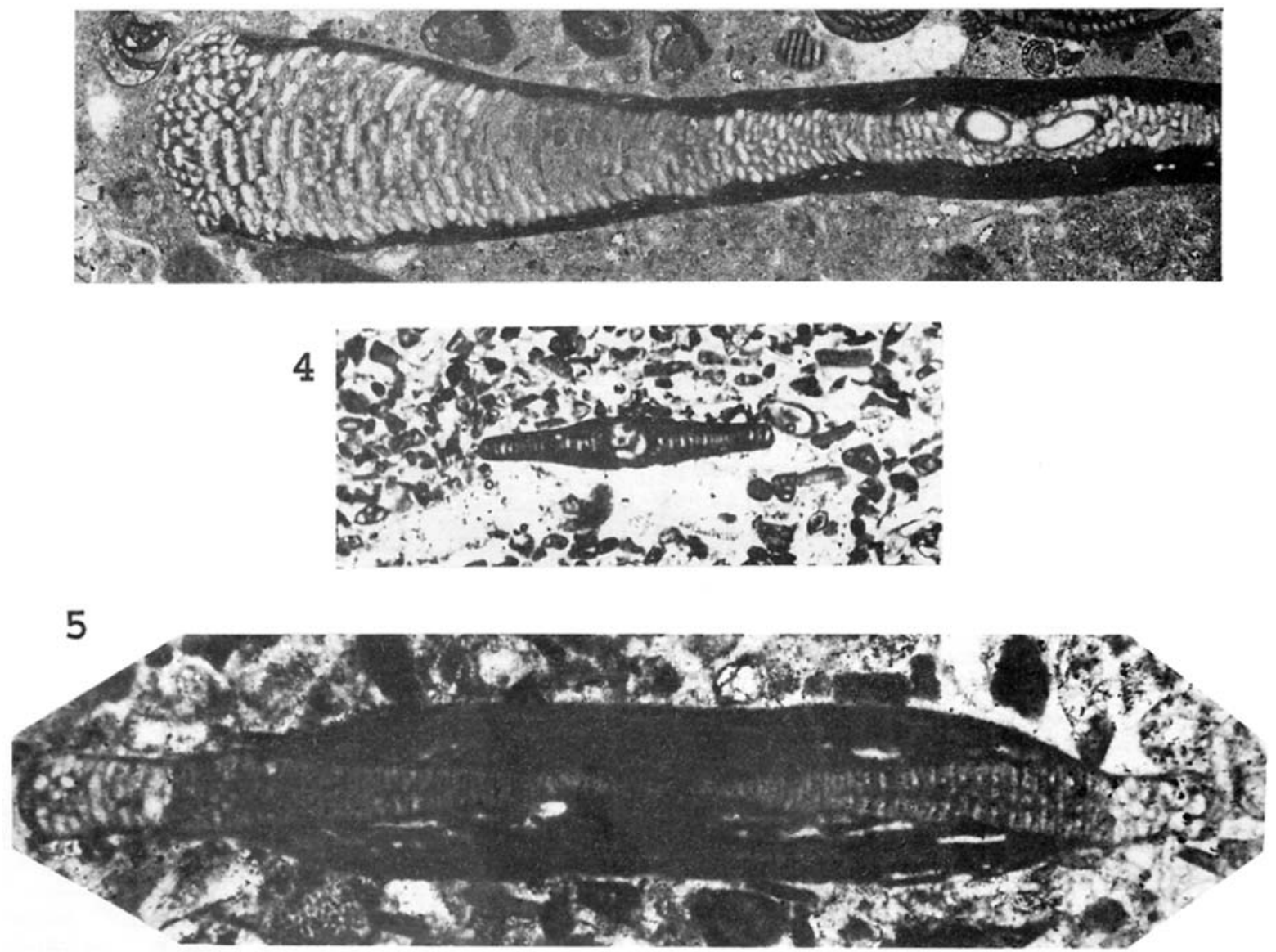

Explanation of Plate 2

Figs 1-2. Somalina hottingeri n. sp. paratypes; 1. Equatorial section of a megalospheric form. Wadi Fatah, F 17. P 52863. $\times 15 ; 2$. Vertical section of a probable microspheric form. Wadi Rusayl, WR 33a. P 52864. $\times 25$. fig. 3. Somalina transitorius (Hottinger). Paratype. Vertical section of a megalospheric form. Ager Valley, west of Agullo, Lerida Province, Spain. Figured by Hottinger in Hottinger \& Krusat (1972), Pl. 8, fig. 2. Naturhistorisches Museum Basel, C 29774. $\times 20$. fig. 4. Opertorbitolites $\mathrm{sp}$. cf. O. gracilis Lehmann. Vertical section through a megalospheric form. Wadi Rusayl, WR 33a. P 52865. $\times$ 20. Note relatively unthickened lateral walls and lenticular shape. fig. 5. Opertorbitolites sp. cf. $O$. douvillei Nuttall. Vertical section of a probable microspheric form. Wadi Rusayl, WR 8. P 52866. $\times 30$. Note relatively thickened lateral walls without the test being lenticular (see text for discussion). 
Type locality. Wadi Rusayl (approximately $56^{\circ} 16^{\prime} \mathrm{E}, 23^{\circ} 75^{\prime} \mathrm{N}$ ), northeastern Oman.

Type level. Middle Eocene (early Alveolina stipes Zone).

Occurrence. Wadi Fatah (F 12, 16, 17, 18, 19, 20); Jebel Hafit (HN 1157, 1155, 1154); Wadi Bani Khalid (WB 9, WBK 2, 4, 5, 10); Wadi Rusayl (WR 33a, 46, 49a, 51, 52, 56, 59, 60) and Wadi Tiwi (HN 1189, 1188).

Type description. Megalospheric test medium to large, lenticular, occasionally slightly to strongly undulate. Surface smooth. Embryonic apparatus comprising a small proloculus and a flexostyle. Post embryonic chambers arcuate, not increasing in height significantly from the centre to the periphery of the test. The lateral walls attain a thickness of up to $0.8 \mathrm{~mm}$ over the umbo and are partially vacuolate.

Microspheric test of medium size with partially vacuolate lateral walls (see Remarks below).

Dimensions of holotype. $(\mathrm{mm})$

Diameter 21

Height at centre $\quad 1.83$

Height at periphery $\quad 0.41$

\section{Dimensions of megalospheric paratypes.}

No. of

specimens Max. Min. Mean

$\begin{array}{lllll}\text { Diameter }(\mathrm{mm}) & 3 & 11.60 & 5.76 & 10.15 \\ \text { Height at centre }(\mathrm{mm}) & 2 & 1.36 & 0.80 & 1.08 \\ \begin{array}{c}\text { Height at periphery }(\mathrm{mm}) \\ \begin{array}{c}\text { Max. internal diameter of } \\ \quad 2\end{array} \\ \quad \text { proloculus }(\mu \mathrm{m})^{*}\end{array} & 0.40 & 0.20 & 0.30 \\ & 2 & 400 & 360 & 380\end{array}$

${ }^{*}$ measured in equatorial section

\section{Dimensions of microspheric paratypes.}

No. of specimens Max. Min. Mean

$\begin{array}{lllll}\text { Diameter }(\mathrm{mm}) & 3 & 8.4 & 8.00 & 8.26\end{array}$

Remarks. The only specimen in which a microspheric embryonic apparatus has been seen (Sample WR 33a; Pl. 2, fig. 1), occurs together with specimens that also appear to belong to this generation (e.g. Pl. 2, fig. 2). These have smooth surfaces and post embryonic chambers that do not increase significantly in height from the centre to the periphery of the test. Microspheric and megalospheric forms have not been recorded together. However, the vacuolate nature of the lateral wall, and the low chambers apparently present in both generations leaves little doubt that they belong to the same species.

Although $S$. hottingeri is characterized by having partially vacuolate walls, this feature is best seen in tangential or near equatorial sections (e.g. Pl. 1, fig. 5; Pl. 2, fig. 1). S. hottingeri differs from $S$. transitorius in having low equatorial chambers throughout the test, and from all other species of this genus by its partially vacuolate lateral lamellar walls.

Faunal association. Nummulites sp. Alveolina drobneae White, $A$. elliptica nuttalli Davies, A. frumentiformis Schwager, A. lukasi White, $A$. cf. rugosa Hottinger, $A$. cf. schwageri ChecchiaRispoli, A. stercus muris Mayer-Eymer, A. cf. subpyrenaica flosculina Silvestri, Assilina, Dictyoconoides cooki (Carter), Linderina rajasthanensis Singh, Lockhartia hunti Ovey, Opertorbitolites ef. gracilis (Lehmann), Somalina stefaninii.
Stratigraphic range. Early to Middle Eocene (probably late Alveolina violae Zone to early Alveolina stipes Zone; see White, 1994, figs 14.7, 14.9, 14.11, 14.12 and 14.15).

\section{DISCUSSION}

Lehmann (1961) distinguished two groups of Opertorbitolites with relatively low equatorial chambers throughout the test, and separated $O$. latimarginalis (Lehmann), in which the equatorial chambers increase significantly in height towards the periphery. $\mathrm{He}$ regarded biplanar forms with only slightly thickened lateral walls as belonging to his biplanus Group and placed those with lenticular tests and strongly thickened lateral walls in that of $O$. douvillei. Forms with relatively unthickened lateral walls, however, may also be lenticular (e.g. $O$. sp. cf. $O$. gracilis Lehmann, Pl. 2, fig. 4), and those with thick lateral walls are not always so (e.g. $O$. sp. cf. O. douvillei, Pl. 2, fig. 5). Consequently, the present author does not recognize the distinction between these two groups. Instead, the $O$. douvillei Group of Lehmann is redefined here to comprise species (including those originally placed by Lehmann in his douvillei and biplanus groups) characterized by relatively low equatorial chambers. The $O$. latimarginalis Group is introduced for those species with equatorial chambers that increase significantly in height towards the periphery of the test.

The low equatorial chambers in $S$. hottingeri, combined with its partially vacuolate lateral walls and its first appearence in the late Early Eocene strongly suggest that it evolved from the $O$. douvillei Group, probably $O$. douvillei itself which is known from the Laki Series (Early Eocene) in Pakistan (Nuttall, 1925). In contrast, the relatively rapid increase in height of the equatorial chambers in $S$. transitorius implies that this arose from $O$. latimarginalis (Alveolina trempina Zone, see Lehmann, 1961), the only known species belonging to the $O$. latimarginalis Group.

From the above, it seems certain that $S$. hottingeri and $S$. transitorius belong to separate lineages (Fig. 2). Of these, the latimarginalis-transitorius line does not appear to have evolved

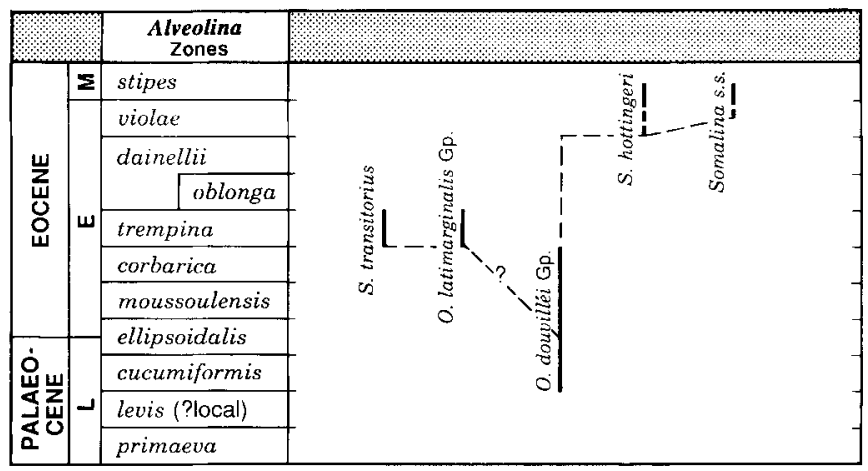

Fig. 2. Suggested evolutionary relationships between the Opertorbitolites douvillei Group, the $O$. latimarginalis Group, Somalina transitorius, $S$. hottingeri and Somalina sensu stricto. Vertical solid and dashed lines denote definite and inferred ranges, respectively. Both $S$. hottingeri and Somalina s.s. are known from the Early Eocene. Although the zone has not been identified, they must at least range into that of Alveolina violae. The $A$. corbarica occurrence of the $O$. douvillei Group is that of $O$. biplanus, recorded by Lehmann (1961). The range of S. transitorius is taken from Hottinger \& Krusat (1972), while that of the $O$. latimarginalis Group (i.e. O. latimarginalis) is from Lehmann (1961). 
further. On the other hand, the close similarity between $S$. hottingeri and Somalina sensu stricto (particularly their low equatorial chambers) leaves little doubt that they belong to a single evolutionary lineage. The later appearance of $O$. latimarginalis compared with the $O$. douvillei Group is tentatively interpreted as the former having evolved from the latter. It is of course possible that the two Opertorbitolites groups have separate origins.

The relatively short combined stratigraphical range of $S$. transitorius and $S$. hottingeri (i.e. Alveolina trempina -- early Alveolina stipes zones) makes their characteristic wall structure a useful age indicator even when the species cannot be identified (e.g. from fragments in thin section).

\section{ACKNOWLEDGEMENTS}

Thanks are extended to J. E. Whittaker, British Museum (Natural History) for organizing the photography of Opertorbitolites douvillei and Somalina transitorius, and for commenting on the text. Thanks also to Lyn Broadbridge, Mines and Energy, South Australia, for printing the other illustrated specimens. A special thank you is extended to the late C. G. Adams for his support during research that led to this paper.

\section{Manuscript received March 1995 \\ Manuscript accepted April 1995}

\section{REFERENCES}

Hottinger, L. \& Krusat, G. 1972. Un foraminifère nouveau intermédiaire entre Opertorbitolites et Somalina de l'Ilerdien Pyrénéen. Revista Española de Micropaleontologia, num. ext, 249-271, pls 1-8.

Lehmann, R, 1961. Plusieurs types morphologiques distincts d'Orbitolites de l'Ilerdien Pyreneen. Bulletin de la Société géologique de France, Ser 7, 4: 357-361, pls 9-10.

Loeblich, A. R. \& Tappan, H. 1987. Foraminiferal Genera and their Classification. Vol. 1, i-x, 1-970; Vol. 2, i-viii, 1-212, pls 1-847. Van Nostrand Reinhold, New York, USA.

Nuttall, W. L. F. 1925. The stratigraphy of the Laki Series (Lower Eocene) of parts of Sind and Baluchistan (India); with a description of the larger foraminifera contained in those beds. Quarterly Journal of the Geological Society, London, 81: 417-452, pls 23-27.

Silvestri, A. 1939. Foraminiferi dell' Eocene della Somalia. Palaeontographica italica, 32: 1-102, pls 1-12.

White, M. R. 1994. In Simmons, M. D. (Ed.) Micropalaeontology and Hydrocarbon Exploration in the Middle East. British Micropalaeontological Society Publication Series,. 309-341, pls 14.1-14.4. Chapman \& Hall, London. 